\title{
Institutional Isomorphism and Adoption of International Public Sector Accounting Standards by African Countries
}

\author{
Dr. Muganda Munir Manini
}

Department of Business Administration and Management, Kibabii University, Kenya

\begin{abstract}
The international harmonization of financial reporting standards in the public sector is one of the significant public sector accounting reforms which have gained prominence in the recent past under the New Public Financial Management order. However, previous empirical evidence provided mixed results on the extent of African countries' decision on the adoption of International Public Sector Accounting Standards and its relationship with institutional isomorphism factors. The purpose of this study was to examine the influence of institutional isomorphism (normative, mimetic and coercive) on the adoption International Public Sector Accounting Standards by African countries. The target population was 54 countries; however the final sample was 29 countries which comprised the dataset. A logistic regression analysis was thereafter conducted. Based on the Institutional Theory, the study revealed external public funding (coercive isomorphic pressure), the countries' global competitiveness (mimetic isomorphic pressure), and human capital (normative isomorphic pressure) were non significant factors in a countries decision to adopt IPSAS. This study contributes to the literature on the international accounting in the public sector. The results of the study have significant managerial and theoretical implications for accounting standards regulators, researchers, and multilateral organizations.
\end{abstract}

Key words: Institutional isomorphism; public sector; IPSAS adoption; Africa and Institutional Theory

\section{0 Introduction}

The nexus between public accounting standards and their role in improving accountability, transparency and management of public resource has become one of the most contemporary issues in recent times (Arnold and Sikka, 2001; McSweeney, 2009; and Sikka, 2015). However as observed by Iyoha and Oyerinde (2010) and Okaro, (2004) institutionalization of these standards in African countries has been poor due patronage, corruption ineffective governance structures and weak regulation frameworks. As a response to the unique challenges facing developing countries, International Financial institutions notably the World Bank and International Monetary Fund have financed these countries in adopting public sector reforms such as the adoption and diffusion of the International Public Sector Accounting Standards (IPSAS). This level of support indicates the importance attached to accounting as a propeller of both structural and economic policy change (Hopper et al., 2012; IMF, 2008). In an effort to attract international capital flows, a number of countries in developing countries have been implementing these reforms aimed at improving transparency and accountability in the public sector. Despite the increasing widespread acceptance of these standards globally, little empirical evidence on the institutional isomorphism influencing IPSAS adoption has been undertaken. Majority of previous studies have focused on the investigation of factors associated with International Accounting Standards and International Financial Reporting Standard adoption (Archambault \& Archambault, 2009; Alon \& Dwyer, 2014; Clements, Neill, \& Stovall, 2010).

DiMaggio and Powell (1983) asserts that institutional isomorphism is a state where institutions in an environment become more homogeneous for social, political or legitimacy purposes by succumbing to the intensity of societal and political pressure. As observed by (Judge, Li, \& Pinsker, 2010; Mnif Sellami \& Gafsi, 2017; Tahat, Omran, \& AbuGhazaleh, 2018) by understanding the organizational field for the 
presence of these institutional pressures, it is theorized that one is better able to understand convergence on homogenized practices and institutionalized behaviors, or how an organizational field becomes institutionalized, around a particular idea or practice. The coercive, mimetic, and normative forces present in the field dictate the institutionalization of organizations. These three pressures, coercive, mimetic, and normative, produce an environment that spurs organizational conformity, or homogeneity, through pressure to appear legitimate, competition mandates associated with funding, and influential professional group and network values. Further, isomorphic change happens when institutions are greatly influenced by institutional environments that dictate how legitimate, successful organizations should look and behave and constrain the ability and motivation of their decision makers to conceive of and implement certain types of organizational change.

The purpose of this article is to examine the institutional isomorphism factors influencing African countries decision to adopt IPSAS. This study was motivated to fill the gap in the prior literature by examining the institutional isomorphism factors associated with countries' decision of adopting IPSAS. There has been little empirical research which has focused only on African countries. Mnif Sellami \& Gafsi, 2017 study include 21 African countries in their sample of 110 countries. These study did not attempt to isolate factors were more significant in one particular region as compared to another, such as Africa only. The purpose of this research is to focus only on African countries and identify factors influencing the adoption of IFRS in African countries. Secondly, if isomorphism exist then studies that explore organizational change using an institutional isomorphic framework are important as these studies can illuminate key aspects of organizational change such as efficiency, innovation, and effectiveness. Finally, the changing governance structures and demand for high-quality accounting standards (IPSAS) to resolve public sector accounting's failures is paramount subject under the New Public Management Theory. This study makes important contribution to the literature on the international accounting in the public sector. The results of the study have significant managerial and theoretical implications for accounting standards regulators, researchers, and multilateral organizations.

The paper is structured as follows: Section one review the literature on institutional isomorphism practices and the theoretical framework guiding the study. Section two explains the methodology used in the study and is followed by the next section presenting the results. The final section concludes the study, makes implications of the findings, highlights limitations and offers suggestions for future research.

\subsection{Literature Review and Hypotheses Development \\ 2.1 Theoretical Framework}

The New Public Management and the Institutional theories are the fundamental theoretical framework in this study. The theories that have been included in the majority of the studies in IPSAS and IFRS include institutional theory (Ahn, Jacobs, Lim, \& Moon, 2014; Baker \& Rennie, 2006; Mnif Sellami \& Gafsi, 2017; Pilcher, 2011);), the economic regulation theory(Leuz \& Wysocki, 2016; Mnif Sellami \& Gafsi, 2017; Stigler, 1971), and the New Public Management (Agasisti, Catalano, Di Carlo, \& Erbacci, 2015; Christiaens \& Rommel, 2008; Paulsson, 2006)

The Institutional Theory emphasizes the importance of institutional pressures (isomorphism) on the institutions/entities practices and on the strategic decisions of economies seeking to legitimize national best practices by implementing globally accepted models. These pressure create a nation's isomorphism (Ahn et al., 2014; DiMaggio \& Powell, 1983, 2000; Judge et al., 2010). DiMaggio and Powell (1983), opine that institutional isomorphism is a state where institutions in an environment become more homogeneous for social, political or legitimacy purposes by succumbing to the intensity of societal and political pressure. As a reaction to this pressure, institutions try to conform to "best practices" and 'legitimate coercion' to legitimize themselves to the public. According to DiMaggio \& Powell, (2000) there are three mechanisms through which institutional isomorphism change occurs namely coercive, mimetic and normative.

Coercive isomorphism emanates from political influence and organizational legitimacy, conveyed through laws, regulations, and accreditation processes (or other outside agency standardization or oversight and compliance requirements). It arises from both formal and informal pressures exerted on organisations by 
other organisations upon which they are dependent. Coercive pressures are majorly exerted by international donors or lending institutions requiring high-quality financial statements and financial reporting as a condition for their financial assistance(DiMaggio \& Powell, 2000; Madawaki, 2012; Oulasvirta, 2014; D. Perera \& Chand, 2015). Coercive pressures that would lead to organizational isomorphism include financial reporting requirements, government mandates, systems of contract law, the budget cycle and regulatory agencies.

Normative isomorphism arises from the influence of "normal" standards, conduct, and working conditions largely exerted by professions and professional groups. It emphasizes uniform behavior by members of distinguishable professional groups. According to (DiMaggio \& Powell, 2000; Mnif Sellami \& Gafsi, 2017; Pilcher, 2011) IPSAS adoption may be enhanced and stimulated by external parties' pressures and the need to legitimize internal practices. Professional networks and expert groups facilitate information exchange across organizations by creation, development, and diffusion of professional standards and new practices (DiMaggio and Powell, 1983).Mimetic isomorphism is a response to uncertainty where an organization or a nation 'mimics', imitates or models itself after other organizations or nations that are deemed to be successful and legitimate to enhance legitimacy or minimize loss of legitimacy (DiMaggio \& Powell, 2000; Mnif Sellami \& Gafsi, 2017).

Mimetic pressures arise from global governance, globalization, foreign trade openness, and the global competition pushing (legitimate coercion)' countries to adopt "best practices" such as international accounting standards(Judge et al., 2010). In the context of this research, national governments in Africa are expected to look at other national governments as exemplars for best practices in IPSAS adoption.

Under the New Public Management, the adoption of private-sector management practices improves the efficiency and effectiveness of, and the accountability for, public services(Gruening, 2001; Hood, 1995; N. B., 2014; Negara, 2015; Osborne, Radnor, \& Nasi, 2013; Usang, Salim, Usang, \& Salim, 2015). The NPM replaced the 'progressive' models of public accountability, as it focuses on controlling inherent corruption in public organizations through elaborate rules and procedures (Gruening, 2001; and Hood, 1995).Proponents argue that the NPM emphasizes accountability for results instead of processes through accrual accounting adoptions as a key tool of "accountingization' of the public sector (Hood, 1995). This enhances greater visibility, influence government accounting (Pina et al., 2009), and elevates the role and status of publicsector accountants and auditors (Caperchione, 2006). The development of NPM is viewed as mechanism to enhance accountability and transparency of governments and this requires financial information are comparable, relevant and useful for decision-making within the public sector(Agasisti et al., 2015; Christiaens \& Rommel, 2008; Rodríguez Bolívar \& Galera, 2016). Therefore, within the public sector IPSAS and IFRS could provide the benchmark for improving the quality of financial reporting(NavarroGalera \& Rodríguez-Bolívar, 2010; Rodriguez Bolivar \& Galera, 2007; Rodríguez Bolívar \& Galera, 2016).

The weakness of the NPM theory as highlighted by (Deaconu, Nistor, \& Filip, 2011; Hood, 1995; Lapsley \& Pallot, 2000; Negara, 2015; S. Perera, Schoch, \& Sabaratnam, 2007; Ryan, Mellett, Moll, \& Hoque, 2008; Usang et al., 2015) is that governments are under pressure to "modernize" their public sectors and as a result of this not-for-profit local governments are being pressured by regulatory and legislative bodies to produce attractive bottom-line results and myriad performance indicators. In addition, public institutions are being coerced to introduce private sector accounting standards in the way of accrual accounting into a public sector environment creating addition stress on discipline and frugality in resource use by emphasis performance compared to strategies(Bellanca \& Vandernoot, 2013; Brusca \& Martínez, 2016; Christiaens \& Rommel, 2008; Gruening, 2001; N. B., 2014; Osborne et al., 2013). There are various interpretations of NPM since Hood, given the underlying purpose of this paper is to examine the implementation of IPSAS in African countries these other forms are not referred to here.

\subsection{Hypotheses Development}

Given the above theoretical explanations and previous studies three hypotheses will be tested in this study.

\subsubsection{Coercive Isomorphism and Adoption of IPSAS}

The adoption of International Public Sector Accounting Standards (IPSASs) in particular the Accrual Basis 
IPSAS has now become a priority for the International Financial Institutions (IFIs), particularly the World Bank and the International Monetary Fund (IMF) and other donors in less developed countries (LDCs). They have therefore provided financial support to encourage these nations to adopt Western accounting reforms such IFRS and IPSAS (Bakre, Lauwo, \& McCartney, 2017).

As emphasized by the institutional theory, these multilateral institutions support the streamlining the accounting system in these countries in accordance with "world's best practices" with the belief it will result in consistency and transparency in the financial management of the country, ensure good governance, boost the confidence of investors, and contribute to strengthening the economy as well as the need for fiscal consolidation (Javed \& Zhuquan, 2018; Mnif Sellami \& Gafsi, 2017). Hence, to encourage effective management of public resources, accountants and auditors are expected to adhere to the existing accounting and auditing rules and regulations to deliver accountability, ensuring a more equitable distribution of wealth in society (OECD, 2003) As Mnif Sellami \& Gafsi, (2017,p.122) assert that, "the level of financial dependence to global financial system increases the sensitivity of countries to external coercive pressures which compels them to adopt the foreign practices such IPSAS". Their result revealed a positive influence of external public funding (coercive isomorphic pressure), the degree of external openness (mimetic isomorphic pressure), and public sector organizations' importance on IPSAS adoption.

Consequently, the need for foreign aid, international financial capital/inflows has compelled most African countries to embark on Financial and Economic Reforms aimed at improving accountability in the management of public resources (Annisette, 2004). As observed by Bakre et al., (2017) IPSASs, is a highquality accounting standards being utilized globally by public-sector entities in the preparation of general purpose financial reports which could improve transparency and accountability in the management of public resources. Further, the "Big Four" accounting firms have actively provided legitimacy to the global adoption of IPSAS, especially in disadvantaged countries (Annisette, 2004). Therefore, it is expected that countries that are highly dependent on financial assistance, will adopt and implement Western accounting reforms such IPSAS to partake in the "benefits" promised by neoliberalism, which include; improving governance, accountability and attracting international capital,(Baker \& Rennie, 2006; Bakre et al., 2017). Thus the following hypothesis is formulated:

$\mathrm{H}_{1}$ : Coercive isomorphism has a significant influence on adoption of IPSAS among African countries

\subsubsection{Mimetic Isomorphism and Adoption of IPSAS}

Institutional theory explains organizational change is driven by "formal legitimacy," or the need to "conform to expectations of key stakeholders in their environment" by copying, imitating or mimicking (mimetic pressures) other organizations or nations that are deemed to be successful (Ashworth, Boyne, \& Delbridge, 2009). According to Judge et al., (2010) mimetic pressures emanate from global governance, globalization, foreign trade openness, and the global competition pushing (legitimate coercion)' countries to adopt "best practices" such as international accounting standards. Christiaens, Reyniers, \& Rollé, (2010) and Mnif Sellami \& Gafsi, (2017) accede that the globalization in economic activity impact on the globalization and harmonization of accounting practices and standards such as IPSAS in the public sector.

Yapa \& Ukwatte (2015) and Tolofari (2005) suggest that the adoption of corporate attitudes and practices in the public sector is focused on neoliberalism and agency framework with heavy emphasis on privatization, managerialism, accountability and performance measurement. They suggest that institutions that lack the ability to adopt new technologies tend to imitate best management practices, including performance measurement, from other successful institutions within the industry. This propensity to imitate the practices of successful institutions occurs due to the need to gain legitimacy from their environment. Flynn, Moretti, \& Cavanagh (2016)suggest that an organization assumes that imitation of successful management practices, accounting standards, leads to cost saving and improved efficiency, and helps them to gain legitimacy.

In the African countries context, according to the World Economic Forum Global Competitiveness Report 2017/2018 African countries made up 17 of the bottom 20 nations. While the global median score is 60 , the 
median in sub Saharan Africa (45.2) was the lowest for all the regions analyzed. The annual index ranks countries based on 12 pillars based broadly on these factors: an enabling environment, markets, human capital and an innovation ecosystem. This poor performance has been attributed to weak institutions, administrative complexity, inadequate public policies, poor infrastructure, skills deficit and challenge of countries in the continent to fill the technology gap despite strong economic growth. (Schwab, 2017; World Economic Forum, 2017). Therefore, in an effort to increase their global competitiveness index, attract foreign direct investment (FDI) and strengthen their competitive position on a global scale African countries like Kenya, South Africa and Nigeria are harmonizing their accounting standards in the public sector with the global standards by embracing transparency and comparable financial reporting (Dabbicco, 2013; Judge et al., 2010; Pina \& Torres, 2009; Torres \& Pina, 2003). DiMaggio \& Powell, (1983) advance the theoretical concept of mimetic isomorphism by affirming that organizations compete for resources, customers, political power, and institutional legitimacy, social and economic fitness. Judge et al., 2010 and Pina \& Torres, 2009) confirm that indeed institutional theorists agree that the status of an organization has an impact on the degree at which they appear isomorphic to the institutional practices of their environment. Mnif Sellami \& Gafsi (2017) posit that the degree of external openness (mimetic isomorphic pressure) stimulate the extensive adoption of IPSAS in the selected countries. Hence, the study proposes the following hypotheses:

$\mathrm{H}_{2}$ : Mimetic isomorphism has a significant influence on adoption of IPSAS among African countries

\subsubsection{Normative Isomorphism and Adoption of IPSAS}

Normative pressure emanates primarily from values of professionalism(Christiaens \& Rommel, 2008; Judge et al., 2010; Tahat et al., 2018). Professionalism is concerned with the members of an institution and their desire to maintain autonomy over work process, procedures and legitimization of their work. Institutional practices, including professions, programs, and technologies, function as myths and organizations adopt them ceremonially.

Within the institutional theory, normative pressures such professional networks or boards, on-the-job socialization and networking, training or professional development, formal education, and certification processes accredited by professional bodies enhance the development and diffusion of professional standards such as IPSAS and/or IFRS (Dabbicco, 2013; Pilcher, 2011; Pina \& Torres, 2009).

Mir \& Sutiyono (2013) explored the public sector financial management reforms of local government agencies in Indonesia using a multiple case study approach. The results showed that there was imbalance between the demand of, supply for, and the quality of the accounting information. There exists a pseudo demand for accounting information for decision-making but the public sector executives rarely use accounting information in decision-making. In addition there was a problem with the production of the information as there were no qualified accountants conversant with the public sector accounting standards and its application.

Mnif Sellami \& Gafsi (2017) examined the institutional and environmental factors affecting the IPSAS adoption decision for a sample of 110 countries. Based on institutional theory and theory of economic regulation, the results revealed that education level (normative isomorphic pressure) was a non significant factor. Tahat, Omran, \& AbuGhazaleh (2018) examined the factors affecting the development of accounting practices in Jordan by surveying the perceptions of 306 participants and 20 interviewees based on institutional theory. The results showed government of Jordan (regulatory frameworks), pressures from international donors and large economic organizations (politico-economic factors), education and training/development (cultural inputs), and the efforts to attract foreign investments and getting access into the international fund and trade (economic factors) have been influential influences in the development of accounting practices and the adoption of International Accounting Standards.

Tanjeh (2016) investigated the factors influencing the acceptance of government accounting reforms in general and IPSAS in particular in Cameroon. A survey was conducted in the Ministry of Finance (MINFI) and the Ordinary Least Squares (OLS) and Ordered Logistics Estimation techniques used. The results findings revealed the determining factors of IPSAS acceptance in Cameroon were knowledge and awareness, institutional organization, staff training and recruitment, management information system, 
qualification, sex, implementation cost, political support, and age. Consequently, the adoption of IPSAS in Cameroon was positively associated with the level of accounting training, education and qualification of staff. These findings were affirmed by (Bdour, Al-Momany, \& Qaqish, 2009; Flynn et al., 2016; Gruening, 2001; Jagalla, Becker, \& Weber, 2011; Javed \& Zhuquan, 2018; Judge et al., 2010; Madawaki, 2012)who observed that in developing economies most human resources and capital goods are allocated to agriculture and manufacturing sectors and investment in the accounting information infrastructure is minimal. Madawaki (2012) asserts that an increase in the education level in a country may increase political awareness and demand for accountability. It is therefore hypothesized that:

$\mathrm{H}_{3}$ : Normative isomorphism has a significant influence on adoption of IPSAS among African countries

\subsection{Research Methodology \\ 3.1 Research Design}

The aim of this study was to examine the influence of institutional isomorphism factors on adoption of international public sector accounting standards in African countries. Thus, in order to accomplish this objective a quantitative research approach was adopted.).

\subsection{Sample and Data Sources}

The target population consisted of all African countries classified as IPSAS adopters and non-adopters. The nations' IPSAS adoption status was provided on the IFAC's website. The initial sample consisted of 54 African countries; 25 countries were excluded due to lack of information on the IPSAS adoption status, presence of outliers and missing data on key explanatory variables. As observed by Stainbank (2014) in African countries there is limited information on their accounting practices and for some countries it was difficult to determine when they had adopted the global accounting standards. The final sample is composed of 29 countries consisting of both adopter and countries and IPSAS non-adopting countries. These countries were classified as non-adopters until the year 2017. In this research, IPSAS adoption by countries may be full or partial (cash and/or accrual). The nation's adoption status is presented in Table 3

Table 1: IPSAS adoption' status of the sample countries

\begin{tabular}{|l|r|}
\hline Country & $\begin{array}{l}\text { IPSAS } \\
\text { Adoption }\end{array}$ \\
\hline Algeria & 1 \\
\hline Benin & 1 \\
\hline Botswana & 1 \\
\hline Cameroon & 1 \\
\hline Chad & 1 \\
\hline Democratic Republic of Congo & 1 \\
\hline Egypt & 0 \\
\hline Eswatini (formerly Swaziland) & 0 \\
\hline Ethiopia & 1 \\
\hline Ghana & 1 \\
\hline Guinea & 1 \\
\hline Kenya & 1 \\
\hline Liberia & \\
\hline
\end{tabular}


Source: IFAC, 2017

\begin{tabular}{|l|r|}
\hline Madagascar & 1 \\
\hline Malawi & 1 \\
\hline Mali & 1 \\
\hline Mauritania & 0 \\
\hline Mauritius & 1 \\
\hline Morocco & 1 \\
\hline Mozambique & 1 \\
\hline Nigeria & 1 \\
\hline Rwanda & 1 \\
\hline Senegal & 1 \\
\hline Sierra Leone & 1 \\
\hline South Africa & 1 \\
\hline Tanzania & 0 \\
\hline Tunisia & 1 \\
\hline Uganda & 1 \\
\hline Zimbabwe & \\
\hline
\end{tabular}

\subsection{Measurement of Variables}

\section{Dependent variable -IPSAS Adoption}

The dependent variable IPSAS adoption was measured using a dichotomous value which was binary coded as equal to " 1 "if a country had adopted IPSAS and " 0 "if a country had not adopted IPSAS. This was because the study sample was divided into two groups of countries namely adopters and non-adopters.

\section{Independent Variables}

\section{Coercive Isomorphism Factors}

This variable was measured by the amount of external public debt as a percentage of the gross domestic product (GDP)

\section{Mimetic Isomorphism Factors}

This was measured by the nations' level of global competitiveness as represented by the World Economic Forum global competitiveness index. The annual index ranks countries based on 12 pillars based namely: an enabling environment, markets, human capital and an innovation ecosystem.

\section{Normative Isomorphism Factors}

Normative isomorphism was measured by the nations' human capital index which represented the measure of skills and training of the country's labour force. It consists of the knowledge, skills, and health that people accumulate throughout their lives, enabling them to realize their potential as productive members of society.

\section{Control Variables}

Based on previous studies two control variables were selected in this study: financial development and economic growth. Financial development measured the development of the financial markets. It was captured by the level of gross domestic capital formation as a ratio of gross domestic product. Economic growth was measured by the average annual growth rate of real gross domestic product in percentage. These two variables have been widely used in the previous literature and have been shown to have significant 
impact on the development of accounting literature particularly on the adoption of international accounting standards(Judge et al., 2010; Mnif Sellami \& Gafsi, 2017; Stainbank, 2014).

The variables' measures and data sources are described in Table 
Table 2:Variable Measurement

\begin{tabular}{|c|c|c|}
\hline Variables & Measurement & Source(s) \& Year \\
\hline $\begin{array}{l}\text { Independent Variables } \\
\text { Coercive Isomorphism Factor } \\
\text { External Public Debt(EXPD) }\end{array}$ & $\begin{array}{l}\text { External Public Debt as } \% \text { of } \\
\text { GDP }\end{array}$ & $\begin{array}{l}\text { World Bank ; World Bank's African } \\
\text { Development Indicators, } 2017\end{array}$ \\
\hline $\begin{array}{l}\text { Mimetic Isomorphism Factor } \\
\text { Countries' Global } \\
\text { Competitiveness(GC) }\end{array}$ & Global competitiveness index & $\begin{array}{l}\text { (Schwab, 2017; World Economic } \\
\text { Forum, 2017a) }\end{array}$ \\
\hline $\begin{array}{l}\text { Normative Isomorphism Factor } \\
\text { Human Capital (HC) }\end{array}$ & Global Human Capital Index & World Economic Forum(2017b) \\
\hline Dependent Variable & & \\
\hline IPSAS Adoption(IPSASA) & $\begin{array}{l}\text { Binary variable that takes the } \\
\text { value " } 1 \text { " if the country has } \\
\text { already adopted IPSAS and } \\
\text { " } 0 \text { " otherwise }\end{array}$ & IFAC(2017);ACCA(2017) \\
\hline Control Variables & & \\
\hline Financial development(FIND) & $\begin{array}{l}\text { Gross domestic capital } \\
\text { formation as a ratio of gross } \\
\text { domestic product }\end{array}$ & $\begin{array}{l}\text { World Bank's African Development } \\
\text { Indicators, } 2017\end{array}$ \\
\hline Economic growth(ECOG) & $\begin{array}{l}\text { Average annual growth rate of } \\
\text { real gross domestic product in } \\
\text { percentage }\end{array}$ & $\begin{array}{l}\text { World Bank's African Development } \\
\text { Indicators, } 2017\end{array}$ \\
\hline
\end{tabular}




\section{Multivariate Analysis}

Multivariate analysis was applied to examine the effect of the explanatory variables on the dichotomous dependent variable using a logistic regression model presented as follows:

$=\log \left(\frac{p(y=1)}{1-(p=1)}\right)=\beta_{0}+\beta_{1}-x_{Z}+\beta_{2}-x_{Z}+\ldots+\beta_{p}-x_{\text {in }}$

\section{$\log \left[p\left(y=1 / 1-(p=1)=\beta_{0}+\beta_{1}\right.\right.$ EXPD $+\beta_{2}$ GC $+\beta_{3}$ HC $+\beta_{4}$ FIND $+\beta_{5}$ ECOG $+\varepsilon$}

\section{Where:}

EXPD: External Public Debt

GC: Countries' Global Competitiveness

HC: Human Capital

FIND: Financial Development

ECOG: Economic Growth

(p)IPSASA: a dichotomous variable that takes the value " 1 " if the country has adopted IPSAS and

" 0 "otherwise.

$\boldsymbol{\varepsilon}$ : the margin of error.

Ordinary least squares regression (OLS) was not deemed appropriate because the outcome variables examined in this study were expressed as dichotomous. Moreover, the use of dichotomous dependent variables violates the assumptions of normality and homoscedasticity in OLS regressions Binary logistic regression expresses the outcome variable as a logit variable through log-linear transformation, which represents a natural $\log$ of the odds of the outcome variable occurring or not (Field, 2005). In computing binary logistic regression analyses, the study controlled for the influence of financial development and economic growth.

\subsection{Results And Discussions}

\subsection{Descriptive Statistics}

The results of descriptive statistics are summarized. The average relative values for external public debt, global competitiveness, human capital index, financial development and economic growth are 41.193, 3.629, $0.410,25.952$ and 4.210 .

Table 3:Results of descriptive statistics

\begin{tabular}{|l|l|l|l|l|l|l|l|}
\hline Variable & Observations & $\begin{array}{l}\text { Obs. with } \\
\text { missing } \\
\text { data }\end{array}$ & $\begin{array}{l}\text { Obs. without } \\
\text { missing data }\end{array}$ & Minimum & Maximum & Mean & $\begin{array}{l}\text { Std. } \\
\text { deviation }\end{array}$ \\
\hline EXPD & 29 & 0 & 29 & 3.400 & 100.800 & 41.193 & 23.883 \\
\hline GC & 29 & 0 & 29 & 2.890 & 4.520 & 3.629 & 0.454 \\
\hline HCI & 29 & 0 & 29 & 0.300 & 0.600 & 0.410 & 0.067 \\
\hline FIND & 29 & 0 & 29 & 9.700 & 73.800 & 25.952 & 13.618 \\
\hline ECOG & 29 & 0 & 29 & -3.000 & 10.600 & 4.210 & 2.757 \\
\hline
\end{tabular}

\subsection{Inferential Statistics}

The results of the correlation matrix and the VIF test are presented in Table 4.The results of Table 7 show that all correlation coefficients were below 0.9.The presence of multicollinearity was tested by the variance inflation factor (VIF). The VIF results in Table 4 indicate there are no problems with any VIF in excess of 20 and no tolerance below 0.05 and there should not be any problems in regressing the model. In this 
research, the highest VIF value is equal to 2.094 that is below 5. Therefore, there is no multicollinearity among variables. Logistic regression results are presented in Table 4.

Table 4: Results of the Correlation Matrix and the VIF.

\begin{tabular}{|l|r|r|r|r|r|r|r|}
\hline Variables & VIF & \multicolumn{1}{c|}{ EXPD } & \multicolumn{1}{c|}{ GC } & \multicolumn{1}{c|}{ HCI } & \multicolumn{1}{c|}{ FIND } & \multicolumn{1}{c|}{ ECOG } & IPSASA \\
\hline EXPD & 1.249 & $\mathbf{1}$ & -0.083 & 0.228 & -0.033 & -0.012 & -0.308 \\
\hline GC & 1.965 & -0.083 & $\mathbf{1}$ & $\mathbf{0 . 6 5 1}$ & -0.005 & 0.134 & -0.041 \\
\hline HCI & 2.094 & 0.228 & $\mathbf{0 . 6 5 1} *$ & $\mathbf{1}$ & 0.052 & 0.117 & -0.240 \\
\hline FIND & 1.254 & -0.033 & -0.005 & 0.052 & $\mathbf{1}$ & $\mathbf{0 . 4 2 5}$ & -0.150 \\
\hline ECOG & 1.251 & -0.012 & 0.134 & 0.117 & $\mathbf{0 . 4 2 5} *$ & $\mathbf{1}$ & -0.113 \\
\hline IPSASA & 1.182 & -0.308 & -0.041 & -0.240 & -0.150 & -0.113 & $\mathbf{1}$ \\
& & & & & & & \\
\hline
\end{tabular}

*The correlation is significant at the $5 \%$ level

\section{Table 5:Logistics Regression Results}

\begin{tabular}{|l|l|l|l|l|l|}
\hline Variables & Expected Sign & Coefficient $\beta$ & Wald & Significance level(p) & Found Sign \\
\hline Independent variables & & & & & \\
\hline EXPD & + & -0.031 & 1.088 & 0.297 & - \\
\hline GC & + & 1.062 & 0.164 & 0.686 & + \\
\hline HCI & + & -15.498 & 0.721 & 0.396 & - \\
\hline Control Variable & & & & & \\
\hline FIND & + & -0.016 & 0.115 & 0.735 & - \\
\hline ECOG & $+/-$ & -0.255 & 0.537 & 0.464 & - \\
\hline Constant & & 7.753 & 1.510 & 0.219 & \\
\hline $\mathrm{R}^{2}$ Cox and Snell) & & 0.152 & & & \\
\hline $\mathrm{R}^{2}$ (Nagelkerke) & & 0.276 & & & \\
\hline $\mathrm{R}^{2}$ (McFadden) & & 0.206 & & & \\
\hline Model Chi-Square & & 18.482 & & & \\
\hline Sample Size & & 29 & & & \\
\hline
\end{tabular}

Equation of the model (Variable

IPSASA):

Pred $($ IPSASA $)=1 /(1+\exp (-(7.75326767317882-3.08194274289752 \mathrm{E}-02 * \mathrm{EXPD}+1.06171350845836 * \mathrm{GC}-15.497859235$

$0.254883036607642 * \mathrm{ECOG}$

The results in Table 4 show a negative but insignificant influence of external public debt on adoption of IPSAS in African countries. This result contradicts the institutional theory proposition that coercive pressures majorly exerted by international donors or lending institutions require high-quality financial statements and financial reporting as a condition for their financial assistance. The finding implies that those countries with higher level of external public debt do not necessary succumb to coercive pressures exerted by external funding body possibly due to their sovereignty.

From Table 4, there is a positive and insignificant effect of global competitiveness on the countries' decision to adopt IPSAS. This finding contrasts with the OECD (2003) who argue that the development of public sector accounting in most countries arise from the mimetic isomorphic pressures from global market place, globalization and the economic openness. Countries with the highest level of global competitiveness are expected to attract foreign direct investments on the basis of their perceived transparency in information disclosure and reporting standards on the global scale. 
Further, the results in Table 4 show a negative and insignificant influence of human capital on the dependent variable IPSAS adoption. This result is inconsistent with the institutional theory propositions. Within the institutional theory, normative pressures such professional networks or boards, on-the-job socialization and networking, training or professional development, formal education, and certification processes accredited by professional bodies are expected to enhance the development and diffusion of professional standards such as IPSAS and/or IFRS (Dabbicco, 2013; Pilcher, 2011; Pina \& Torres, 2009).

The variables for financial development and economic growth are both statistically insignificant, indicating these factors do not play a significant role on the Africans countries' decision to adopt IPSAS. In summary, the findings of all the study analyses do not support hypotheses $\mathrm{H}_{1}, \mathrm{H}_{2}$, and $\mathrm{H}_{3}$, which are coercive, normative and mimetic isomorphism factors.

\subsection{Conclusion}

This study sought to examine the institutional isomorphism factors influencing IPSAS adoption for a sample 29 African countries within the institutional theory framework. The results showed negative but insignificant influence of external public debt (coercive isomorphic pressure) and human capital (normative isomorphic pressure) on countries' decision to adopt IPSAS. This study is consistent with the results of Mnif Sellami \& Gafsi, (2017) who did not find education level of importance in IPSAS adoption decision by countries. In addition, the finding revealed global competitiveness (mimetic isomorphic pressure) has a positive but insignificant influence on IPSAS adoption.

This research contributes to the public accounting literature by focusing on country level institutional factors which have an influence on IPSAS adoption in Sub Saharan Africa. Further, majority of some studies have examined the IPSAS implementation in single country (Ijeoma \& Oghoghomeh, 2014; Tanjeh, 2016). Hence, no studies have examined the institutional isomorphism factors associated with IPSAS adoption for many of countries in Africa.

The findings of are significant to a number of stakeholders. Firstly, they provide scholars with an in depth understanding of the status of IPSAS adoption among African countries by examining the key institutional isomorphism factors associated with the countries' IPSAS adoption decision. Secondly, they can assist policy makers and accounting regulators in the development and harmonization of public sector financial reporting standards. Lastly, the results may be useful to multilateral agencies such as the IFC, IMF and the World Bank in their lending policies as it provides an understanding on the contextual factors associated with the adoption of IPSAS in African countries. The main limitation of the study is the limited number of African countries examined, however it is anticipated that the number of countries adopting IPSAS will most likely increase. This study opens new area for further research in diffusion of IPSAS. Future research may examine the impact of micro economic and company specific factors on IPSAS adoption.

\section{REFERENCES}

[1] Agasisti, T., Catalano, G., Di Carlo, F., \& Erbacci, A. (2015). Accrual accounting in Italian universities: a technical perspective. International Journal of Public Sector Management, 28(6), 494-508. https://doi.org/10.1108/IJPSM-02-2015-0026

[2] Ahn, P. D., Jacobs, K., Lim, D. W., \& Moon, K. (2014). Beyond Self-Evident: Recognising the Problematic Political Context of Accrual Accounting Adoption in South Korea. Financial Accountability and Management, 30(1), 25-48. https://doi.org/10.1111/faam.12026

[3] Alon, A., \& Dwyer, P. D. (2014). Early adoption of IFRS as a strategic response to transnational and local influence. The International Journal of Accounting, 49, 348-370.

[4] Annisette, M. (2004). The true nature of the World Bank. Critical Perspectives on Accounting. https://doi.org/10.1016/S1045-2354(03)00064-9

[5] Archambault, J. J., \& Archambault, M. E. (2009). An analysis of social factors influencing the adoption of international financial reporting standards. Journal for Global Business Advancement, 2(1/2), 38-53 
[6] Arnold, P.J. and Sikka, P. (2001), "Globalisation and the state-profession relationship: the case of the bank of credit and commerce international”, Accounting, Organizations and Society, Vol. 26 No. 6, pp. 475-499.

[7] Ashworth, R., Boyne, G., \& Delbridge, R. (2009). Escape from the iron cage? Organizational change and isomorphic pressures in the public sector. Journal of Public Administration Research and Theory. https://doi.org/10.1093/jopart/mum038

[8] Baker, R., \& Rennie, M. D. (2006). Forces leading to the adoption of accrual accounting by the Canadian federal government: An institutional perspective . Canadian Accounting Perspectives, 5(1), 83-112. https://doi.org/10.1506/206K-RV7L-2JMN-W3D3

[9] Bakre, O., Lauwo, S. G., \& McCartney, S. (2017). Western accounting reforms and accountability in wealth redistribution in patronage-based Nigerian society. Accounting, Auditing and Accountability Journal, 30(6), 1288-1308. https://doi.org/10.1108/AAAJ-03-2016-2477

[10] Bdour, J. I., Al-Momany, M. T., \& Qaqish, M. H. (2009). Perceptions of government employees about the introduction of accrual-based accounting into the Jordanian Public Sector, 34-66.

[11] Bellanca, S., \& Vandernoot, J. (2013). Analysis of Belgian Public Accounting and Its Compliance with International Public Sector Accounting Standards (IPSAS) 1, 6 and 22. International Journal of Business and Management. https://doi.org/10.5539/ijbm.v8n9p122

[12] Brusca, I., \& Martínez, J. C. (2016). Adopting International Public Sector Accounting Standards: a challenge for modernizing and harmonizing public sector accounting. International Review of Administrative Sciences. https://doi.org/10.1177/0020852315600232

[13] Christiaens, J., Reyniers, B., \& Rollé, C. (2010). Impact of IPSAS on reforming governmental financial information systems: A comparative study. International Review of Administrative Sciences. https://doi.org/10.1177/0020852310372449

[14] Christiaens, J., \& Rommel, J. (2008). Accrual Accounting Reforms: Only for Businesslike (Parts of) Governments. Ssrn, 24(February), 59-75. https://doi.org/10.1111/j.1468-0408.2008.00443.x

[15] Clements, C. E., Neill, J. D., \& Stovall, O. S. (2010). Cultural diversity, country size and the IFRS adoption decision. The Journal of Applied Business Research, 26,2

[16] Dabbicco, G. (2013). The reconciliation of primary accounting data for government entities and balances according to statistical measures: The case of the European Excessive Deficit Procedure Table 2. OECD Journal on Budgeting. https://doi.org/10.1787/budget-13-5k409g5913xq

[17] Deaconu, A., Nistor, C. S., \& Filip, C. (2011). The impact of accrual accounting on public sector management. An exploratory study for Romania. Transylvanian Review of Administrative Sciences.

[18] DiMaggio, P. J., \& Powell, W. W. (1983). The Iron Cage: Institutional Isomorphism and Collective Rationality in Organizational Fields. Amercican Sociological Review. https://doi.org/10.2307/2095101

[19] DiMaggio, P. J., \& Powell, W. W. (2000). The iron cage revisited institutional isomorphism and collective rationality in organizational fields. Advances in Strategic Management. https://doi.org/10.1016/S0742-3322(00)17011-1

[20] Flynn, S., Moretti, D., \& Cavanagh, J. (2016). Implementing Accrual Accounting in the Public Sector. Technical Notes and Manuals, 2016(06), 1. https://doi.org/1-59259-874-9:243 [pii]

[21] Gruening, G. (2001). Origin and theoretical basis of new public management. International Public Management Journal. https://doi.org/10.1016/S1096-7494(01)00041-1

[22] Hopper, T., Tsamenyi, M., Uddin, S. and Wickramasinghe, D. (2012), "Introduction: accounting and development", in Hopper, T., Tsamenyi, M., Uddin, S. and Wickramasinghe, D. (Eds), Handbook of Accounting and Development, Edward Elgar, Cheltenham, pp. 1-14

[23] Hood, C. (1995). The "new public management" in the 1980s: Variations on a theme. Accounting, Organizations and Society. https://doi.org/10.1016/0361-3682(93)E0001-W

[24] IMF (2008), "Fuel and food price subsidies: issues and reform options", International Monetary Fund, Washington, DC, available at: www.imf.org/external/np/pp/eng/2008/090808a.pdf (accessed 10 January 2019).

[25] Iyoha, F.O. and Oyerinde, D. (2010), "Accounting infrastructure and accountability in the management of public expenditure in developing countries: a focus on Nigeria", Critical Perspectives on Accounting, Vol. 21 No. 5, pp. 361-373.

[26] Jagalla, T., Becker, S. D., \& Weber, J. (2011). A Taxonomy of the Perceived Benefits of Accrual Accounting and Budgeting: Evidence from German States. Ssrn, 27(May), 134-165. 
https://doi.org/10.1111/j.1468-0408.2011.00520.x

[27] Javed, M., \& Zhuquan, W. (2018). Analysis of Accounting Reforms in the Public Sector of Pakistan and Adoption of Cash Basis IPSAS. Universal Journal of Accounting and Finance.

https://doi.org/10.13189/ujaf

[28] Judge, W., Li, S., \& Pinsker, R. (2010). National adoption of international accounting standards: An institutional perspective. Corporate Governance: An International Review. https://doi.org/10.1111/j.14678683.2010.00798.x

[29] Lapsley, I., \& Pallot, J. (2000). Accounting, management and organizational change: A comparative study of local government. Management Accounting Research. https://doi.org/10.1006/mare.2000.0129

[30] Leuz, C., \& Wysocki, P. D. (2016). The Economics of Disclosure and Financial Reporting Regulation:

Evidence and Suggestions for Future Research. Journal of Accounting Research.

https://doi.org/10.1111/1475-679X.12115

[31] Madawaki, A. (2012). Adoption of International Financial Reporting Standards in Developing Countries: The Case of Nigeria. International Journal of Business and Management. https://doi.org/10.5539/ijbm.v7n3p152

[32] McSweeney, B. (2009), "The roles of financial assets, market failure denial and the economic crisis: reflections on accounting and financial theories and practices", Accounting, Organizations and Society, Vol. 34 Nos 6/7, pp. 835-848.

[33] Mir, M., \& Sutiyono, W. (2013). Public Sector Financial Management Reform: A Case Study of Local Government Agencies in Indonesia. Australasian Accounting, Business and Finance Journal. https://doi.org/10.14453/aabfj.v7i4.7

[34] Mnif Sellami, Y., \& Gafsi, Y. (2017). Institutional and Economic Factors Affecting the Adoption of International Public Sector Accounting Standards. International Journal of Public Administration, 42(2), 1-13. https://doi.org/10.1080/01900692.2017.1405444

[35] N. B., I. (2014). Adoption of International Public Sector Accounting Standards in Nigeria: Expectations, Benefits and Challenges. Journal of Investment and Management. https://doi.org/10.11648/j.jim.20140301.13

[36] Navarro-Galera, A., \& Rodríguez-Bolívar, M. P. (2010). Can government accountability be enhanced with international financial reporting standards? Public Money and Management. https://doi.org/10.1080/09540962.2010.525009

[37] Negara, S. (2015). Toward Implementation of Accural Basis in Indonesia Government: Key Success Factors. GSTF Journal on Business Review (GBR). https://doi.org/10.5176/2010-4804_4.1.354

[38] Okaro, S. (2004), "Bank failure in Nigeria: an early warning model of corporate distress", The Nigerian Accountant, Vol. 37 No. 4, pp. 23-33

[39] Osborne, S. P., Radnor, Z., \& Nasi, G. (2013). A New Theory for Public Service Management? Toward a (Public) Service-Dominant Approach. American Review of Public Administration. https://doi.org/10.1177/0275074012466935

[40] Oulasvirta, L. (2014). The reluctance of a developed country to choose International Public Sector Accounting Standards of the IFAC. A critical case study. Critical Perspectives on Accounting. https://doi.org/10.1016/j.cpa.2012.12.001

[41] Paulsson, G. (2006). Accrual Accounting in the Public Sector: Experiences from the Central Government in Sweden. Ssrn, 22(February), 47-62. https://doi.org/10.1111/j.0267-4424.2006.00392.x

[42] Perera, D., \& Chand, P. (2015). Issues in the adoption of international financial reporting standards (IFRS) for small and medium-sized enterprises (SMES). Advances in Accounting. https://doi.org/10.1016/j.adiac.2015.03.012

[43] Perera, S., Schoch, H., \& Sabaratnam, S. (2007). Adoption of the Balanced Scorecard in Local Government Organizations: an Exploratory Study. Asia-Pacific Management Accounting Journal.

[44] Pilcher, R. (2011). Implementing IFRS in local Government: Institutional Isomorphism as NPM goes mad? Local Government Studies, 37(4), 367-389. https://doi.org/10.1080/03003930.2011.588702

[45] Pina, V., \& Torres, L. (2009). Reshaping Public Sector Accounting: An International Comparative View. Canadian Journal of Administrative Sciences / Revue Canadienne Des Sciences de l'Administration. https://doi.org/10.1111/j.1936-4490.2003.tb00709.x

[46] Rodriguez Bolivar, M. P., \& Galera, A. N. (2007). Could fair value accounting be useful, under NPM models, for users of financial information? International Review of Administrative Sciences. 
https://doi.org/10.1177/0020852307081153

[47] Rodríguez Bolívar, M. P., \& Galera, A. N. (2016). The Effect of Changes in Public Sector Accounting Policies on Administrative Reforms Addressed to Citizens. Administration and Society. https://doi.org/10.1177/0095399713498751

[48] Ryan, C., Mellett, H., Moll, J., \& Hoque, Z. (2008). New organizational forms and accounting innovations: The specifier/provider model in the Australian public sector. Journal of Accounting \& Organizational Change. https://doi.org/10.1108/18325910810898052

[49] Schwab, K. (2017). The Global Competitiveness Report The Global Competitiveness Report 2017-2018. World Economic Forum. https://doi.org/92-95044-35-5

[50] Sikka, P. (2015), "The corrosive effects of neoliberalism on the UK financial crises and auditing practices: a dead-end for reforms", Accounting Forum, Vol. 39 No. 1, pp. 1-18.

[51] Stainbank, L. J. (2014). Factors Influencing the Adoption of International Financial Reporting Standards by African Countries. South African Journal of Accounting Research, 28(1), 79-95. https://doi.org/10.1080/10291954.2014.11463128

[52] Stigler, G. J. (1971). The Theory of Economic Regulation. The Bell Journal of Economics and Management Science. https://doi.org/10.2307/3003160

[53] Tahat, Y., Omran, M. A., \& AbuGhazaleh, N. M. (2018). Factors affecting the development of accounting practices in Jordan: an institutional perspective. Asian Review of Accounting, 26(4), 464-486. https://doi.org/10.1108/ARA-01-2017-0010

[54] Tanjeh, M. S. (2016). Factors Influencing the Acceptance of International Public Sector Accounting Standards in Cameroon. Accounting and Finance Research. https://doi.org/10.5430/afr.v5n2p71

[55] Tolofari, S. (2005). New Public Management and Education. Policy Futures in Education. https://doi.org/10.2304/pfie.2005.3.1.11

[56] Torres, L., \& Pina, V. (2003). Accounting for Accountability and Management in NPOs. A Comparative Study of Four Countries: Canada, the United Kingdom, the USA and Spain. Financial Accountability and Management, 19(3), 265-285. https://doi.org/10.1111/1468-0408.00174

[57] Usang, O. U. E., Salim, B., Usang, E., \& Salim, B. (2015). A conceptual perspective of internal audit quality and local government performance in Nigeria. International Conference on Accounting Studies (ICAS). https://doi.org/10.5539/ass.v12n4p28

[58] World Economic Forum. (2017). The Global Competitiveness Report The Global Competitiveness Report 2017-2018. World Economic Forum. https://doi.org/92-95044-35-5

[59] Yapa, P. W. S., \& Ukwatte, S. (2015). The New Public Financial Management (NPFM) and accrual accounting in Sri Lanka. Research in Accounting in Emerging Economies. https://doi.org/10.1108/S1479356320150000015002 


\section{APPENDIX 1: XLSTAT OUTPUT}

XLSTAT 2019.1.2.57437 - Logistic regression - Start time: 5/10/2019 at 4:05:16 PM / End time: 5/10/2019 at 4:05:18 PM

Response variable(s): Workbook $=$ IPSAS DATA.xlsx $/$ Sheet $=$ Sheet5 $/$ Range $=$

'Sheet5'!\$G:\$G / 29 rows and 1 column

Quantitative: Workbook = IPSAS DATA.xIsx $/$ Sheet $=$ Sheet5 $/$ Range $=$

'Sheet5'!\$B:\$F / 29 rows and 5 columns

Model: Logit

Response type:

Binary

Confidence interval

(\%): 95

Stop conditions: Iterations $=100 /$

Convergence $=0.000001$

Maximization of the likelihood function using the

Newton-Raphson algorithm

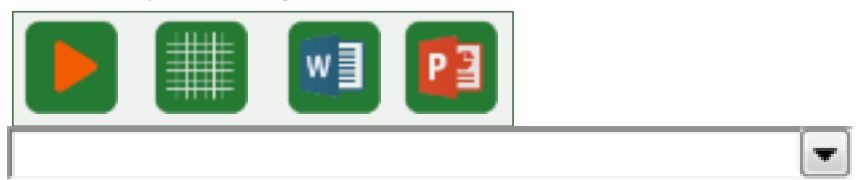

Summary

statistics:

\begin{tabular}{lcrr}
\hline & Cat & & \\
Variab & $\begin{array}{c}\text { eg } \\
\text { ori }\end{array}$ & $\begin{array}{c}\text { Freq } \\
\text { uenc }\end{array}$ & \\
le & es & ies & \multicolumn{1}{c}{$\%$} \\
\hline IPSAS & & & 13.79 \\
A & 0 & 4 & 3 \\
& & & 86.20 \\
& 1 & 25 & 7 \\
\hline
\end{tabular}

\begin{tabular}{|c|c|c|c|c|c|c|c|}
\hline $\begin{array}{c}\text { Variab } \\
\text { le }\end{array}$ & $\begin{array}{c}\text { Ob } \\
\text { ser } \\
\text { vat } \\
\text { ion } \\
\text { s }\end{array}$ & $\begin{array}{c}\text { Obs. } \\
\text { with } \\
\text { missi } \\
\text { ng } \\
\text { data }\end{array}$ & $\begin{array}{c}\text { Obs. } \\
\text { witho } \\
\text { ut } \\
\text { missi } \\
\text { ng } \\
\text { data }\end{array}$ & $\begin{array}{c}\mathrm{Mi} \\
\mathrm{ni} \\
\mathrm{mu} \\
\mathrm{m}\end{array}$ & $\begin{array}{l}\text { Maxi } \\
\text { mum }\end{array}$ & Mean & $\begin{array}{c}\text { St } \\
\text { d. } \\
\text { de } \\
\text { via } \\
\text { tio } \\
\mathrm{n}\end{array}$ \\
\hline & & & & & & & 23 \\
\hline & & & & 3.4 & 100.8 & 41.19 & .8 \\
\hline \multirow[t]{2}{*}{ EXPD } & 29 & 0 & 29 & 00 & 00 & 3 & 83 \\
\hline & & & & 2.8 & & & 45 \\
\hline \multirow[t]{2}{*}{ GC } & 29 & 0 & 29 & 90 & 4.520 & 3.629 & $\begin{array}{l}4 \\
0 .\end{array}$ \\
\hline & & & & 0.3 & & & 06 \\
\hline \multirow[t]{2}{*}{$\mathrm{HCl}$} & 29 & 0 & 29 & 00 & 0.600 & 0.410 & $\begin{array}{r}7 \\
13\end{array}$ \\
\hline & & & & 9.7 & 73.80 & 25.95 & .6 \\
\hline FIND & 29 & 0 & 29 & 00 & 0 & 2 & 18 \\
\hline
\end{tabular}




\begin{tabular}{|c|c|c|c|c|c|c|c|}
\hline & & & & - & & & 2. \\
\hline & & & & 3.0 & 10.60 & & 75 \\
\hline ECOG & 29 & 0 & 29 & 00 & 0 & 4.210 & 7 \\
\hline
\end{tabular}

Correlation

matrix:

\begin{tabular}{lrrrrr}
\hline $\begin{array}{c}\text { Variab } \\
\text { les }\end{array}$ & EX & & & FIN & \\
& GD & HCl & \multicolumn{1}{c}{ D } & ECOG \\
\hline & 1.0 & -0.08 & & - & \\
EXPD & $\mathbf{0 0}$ & 3 & 0.228 & 33 & 0.012 \\
& - & & & - & \\
& 0.0 & $\mathbf{1 . 0 0}$ & & 0.0 & \\
GC & 83 & $\mathbf{0}$ & 0.651 & 05 & 0.134 \\
& 0.2 & 0.65 & & 0.0 & \\
HCl & 28 & 1 & 1.000 & 52 & 0.117 \\
& - & - & & & \\
& 0.0 & 0.00 & & 1.0 & \\
FIND & 33 & 5 & 0.052 & $\mathbf{0 0}$ & 0.425 \\
& - & & & & \\
& 0.0 & 0.13 & & 0.4 & \\
ECOG & 12 & 4 & 0.117 & 25 & $\mathbf{1 . 0 0 0}$ \\
\hline
\end{tabular}

Regression of

variable IPSASA:

Correspondence between the categories of the response variable and the probabilities (Variable IPSASA):

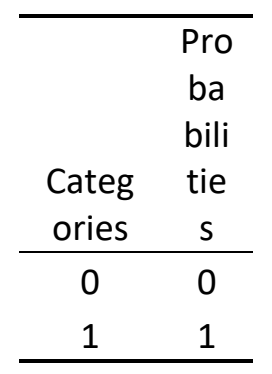

Goodness of fit statistics (Variable IPSASA):

\begin{tabular}{lrr}
\hline & Ind & \\
& ep & \\
& en & \\
Statist & de & \\
ic & nt & Full \\
\hline Obser & & \\
vation & & \\
S & 29 & 29 \\
Sum & 29. & 29.0
\end{tabular}




\begin{tabular}{lrr} 
of & 00 & 00 \\
weigh & 0 & \\
ts & & \\
DF & 28 & 23 \\
-2 & & \\
Log(Li & 23. & \\
keliho & 26 & 18.4 \\
od) & 9 & 82 \\
$\mathrm{R}^{2}(\mathrm{Mc}$ & & \\
Fadde & 0.0 & 0.20 \\
$\mathrm{n})$ & 00 & 6 \\
$\mathrm{R}^{2}$ (Cox & & \\
and & 0.0 & 0.15 \\
Snell) & 00 & 2 \\
$\mathrm{R}^{2}(\mathrm{Na}$ & & \\
gelker & 0.0 & 0.27 \\
ke) & 00 & 6 \\
& 25. & \\
& 26 & 30.4 \\
AIC & 9 & 82 \\
& 26. & \\
& 63 & 38.6 \\
SBC & 6 & 86 \\
Iterati & & \\
ons & 0 & 12 \\
\hline
\end{tabular}

Test of the null hypothesis $\mathrm{HO}: \mathrm{Y}=0.862$ (Variable IPSASA):

\begin{tabular}{lrrr}
\hline $\begin{array}{l}\text { Statist } \\
\text { ic }\end{array}$ & $\begin{array}{c}\text { Chi- } \\
\text { Dq }\end{array}$ & $\begin{array}{c}\text { squa } \\
\text { re }\end{array}$ & $\begin{array}{c}\text { Pr }> \\
\text { Chi }^{2}\end{array}$ \\
\hline-2 & & & \\
Log(Li & & & \\
keliho & & 4.78 & \\
od) & 5 & 7 & 0.442 \\
& & 4.46 & \\
Score & 5 & 0 & 0.485 \\
& & 3.32 & \\
Wald & 5 & 1 & 0.651 \\
\hline
\end{tabular}

Type II analysis (Variable IPSASA):

\section{Chi}

\begin{tabular}{cccccc} 
& & Chi- & & sq & \\
& & squa & & uar & \\
& & re & & e & \\
Sourc & & (Wal & Pr $>$ & (LR & Pr $>$ \\
e & DF & d) & Wald & ) & LR \\
\hline EXPD & 1 & 1.08 & 0.297 & 1.2 & 0.258
\end{tabular}




\begin{tabular}{lrrlrl}
\hline & & 8 & & 82 & \\
& & 0.16 & & 0.1 & \\
$\mathrm{GC}$ & 1 & 4 & 0.686 & 77 & 0.674 \\
& & 0.72 & & 0.9 & \\
$\mathrm{HCl}$ & 1 & 1 & 0.396 & 01 & 0.343 \\
& & 0.11 & & 0.1 & \\
FIND & 1 & 5 & 0.735 & 13 & 0.737 \\
& & 0.53 & & 0.6 & \\
ECOG & 1 & 7 & 0.464 & 32 & 0.427 \\
\hline
\end{tabular}

Hosmer-Lemeshow test (Variable IPSASA):

\begin{tabular}{lcccc}
\hline & Chi & & \\
& - & & \\
Statist & sq & & \\
$\quad$ ic & e & & DF & Pr> \\
Chi $^{2}$ \\
\hline Hosm & & & \\
er- & & & \\
Lemes & & & \\
how & & & \\
Statist & 4.9 & & \\
ic & 70 & 8 & 0.761 \\
\hline
\end{tabular}

Model parameters (Variable IPSASA):

\begin{tabular}{|c|c|c|c|c|c|c|c|c|c|}
\hline $\begin{array}{c}\text { Sourc } \\
\mathrm{e}\end{array}$ & $\begin{array}{l}\text { Val } \\
\text { ue }\end{array}$ & $\begin{array}{l}\text { Stan } \\
\text { dard } \\
\text { error }\end{array}$ & $\begin{array}{l}\text { Wald } \\
\text { Chi- } \\
\text { Squar } \\
\text { e }\end{array}$ & $\begin{array}{c}\mathrm{Pr} \\
> \\
\text { Chi } \\
2\end{array}$ & $\begin{array}{c}\text { Wald } \\
\text { Lowe } \\
r \\
\text { boun } \\
d \\
(95 \%)\end{array}$ & $\begin{array}{c}\text { Wald } \\
\text { Uppe } \\
r \\
\text { boun } \\
d \\
(95 \%)\end{array}$ & $\begin{array}{l}\text { Od } \\
\text { ds } \\
\text { rat } \\
\text { io }\end{array}$ & $\begin{array}{l}\text { Odds } \\
\text { ratio } \\
\text { Lower } \\
\text { bound } \\
(95 \%)\end{array}$ & $\begin{array}{c}\text { Odds } \\
\text { ratio } \\
\text { Upper } \\
\text { bound } \\
(95 \%)\end{array}$ \\
\hline Interc & 7.7 & 6.30 & & 0.2 & - & 20.11 & & & \\
\hline \multirow[t]{2}{*}{ ept } & $\begin{array}{r}53 \\
-\end{array}$ & 9 & 1.510 & 19 & 4.612 & 9 & 0. & & \\
\hline & 0.0 & 0.03 & & 0.2 & - & & 97 & & \\
\hline \multirow[t]{2}{*}{ EXPD } & 31 & 0 & 1.088 & 97 & 0.089 & 0.027 & $\begin{array}{c}0 \\
2 .\end{array}$ & 0.915 & 1.027 \\
\hline & 1.0 & 2.62 & & 0.6 & - & & 89 & & 494.96 \\
\hline \multirow[t]{3}{*}{$\mathrm{GC}$} & $\begin{array}{r}62 \\
-\end{array}$ & 4 & 0.164 & 86 & 4.081 & 6.204 & 1 & 0.017 & 1 \\
\hline & 15. & & & & - & & 0. & & 64496 \\
\hline & 49 & 18.2 & & 0.3 & 51.28 & 20.28 & 00 & & 7892.7 \\
\hline \multirow[t]{2}{*}{$\mathrm{HCl}$} & $\begin{array}{l}8 \\
-\end{array}$ & 57 & 0.721 & 96 & 0 & 5 & $\begin{array}{l}0 \\
0 .\end{array}$ & 0.000 & 32 \\
\hline & 0.0 & 0.04 & & 0.7 & - & & 98 & & \\
\hline \multirow[t]{2}{*}{ FIND } & $\begin{array}{r}16 \\
-\end{array}$ & 7 & 0.115 & 35 & 0.108 & 0.076 & $\begin{array}{l}4 \\
0 .\end{array}$ & 0.898 & 1.079 \\
\hline & 0.2 & 0.34 & & 0.4 & - & & 77 & & \\
\hline ECOG & 55 & 8 & 0.537 & 64 & 0.937 & 0.427 & 5 & 0.392 & 1.532 \\
\hline
\end{tabular}


Equation of the model

(Variable IPSASA):

Pred (IPSASA $)=1 /(1+\exp (-(7.75326767317882-3.08194274289752 \mathrm{E}-$

02*EXPD+1.06171350845836*GC-15.4978592353036*HCI-1.58859319976661E-02*FIND-

$0.254883036607642 * E(O G)))$

Standardized coefficients

(Variable IPSASA):

\begin{tabular}{|c|c|c|c|c|c|c|}
\hline $\begin{array}{c}\text { Sourc } \\
\mathrm{e}\end{array}$ & $\begin{array}{l}\text { Val } \\
\text { ue }\end{array}$ & $\begin{array}{l}\text { Stan } \\
\text { dard } \\
\text { error }\end{array}$ & $\begin{array}{l}\text { Wald } \\
\text { Chi- } \\
\text { Squar } \\
\text { e }\end{array}$ & $\begin{array}{c}\mathrm{Pr} \\
> \\
\text { Chi } \\
2\end{array}$ & $\begin{array}{c}\text { Wald } \\
\text { Lowe } \\
r \\
\text { boun } \\
d \\
(95 \%)\end{array}$ & $\begin{array}{c}\text { Wald } \\
\text { Uppe } \\
r \\
\text { boun } \\
d \\
(95 \%)\end{array}$ \\
\hline & $0 . \overline{3}$ & 0.38 & & 0.2 & - & \\
\hline EXPD & $\begin{array}{r}99 \\
0.2\end{array}$ & $\begin{array}{r}2 \\
0.64\end{array}$ & 1.088 & $\begin{array}{r}97 \\
0.6\end{array}$ & $\begin{array}{r}1.148 \\
-\end{array}$ & 0.351 \\
\hline GC & 0.5 & 0.66 & 0.164 & 0.3 & 1.004 & 1.526 \\
\hline $\mathrm{HCl}$ & $\begin{array}{r}65 \\
-\end{array}$ & 6 & 0.721 & 96 & 1.870 & 0.740 \\
\hline FIND & $\begin{array}{r}0.1 \\
17 \\
-\end{array}$ & $\begin{array}{r}0.34 \\
6\end{array}$ & 0.115 & $\begin{array}{r}0.7 \\
35\end{array}$ & $\begin{array}{r}- \\
0.795\end{array}$ & 0.560 \\
\hline ECOG & $\begin{array}{r}0.3 \\
81\end{array}$ & $\begin{array}{r}0.51 \\
9\end{array}$ & 0.537 & $\begin{array}{r}0.4 \\
64\end{array}$ & $\begin{array}{r}- \\
1.399\end{array}$ & 0.637 \\
\hline
\end{tabular}

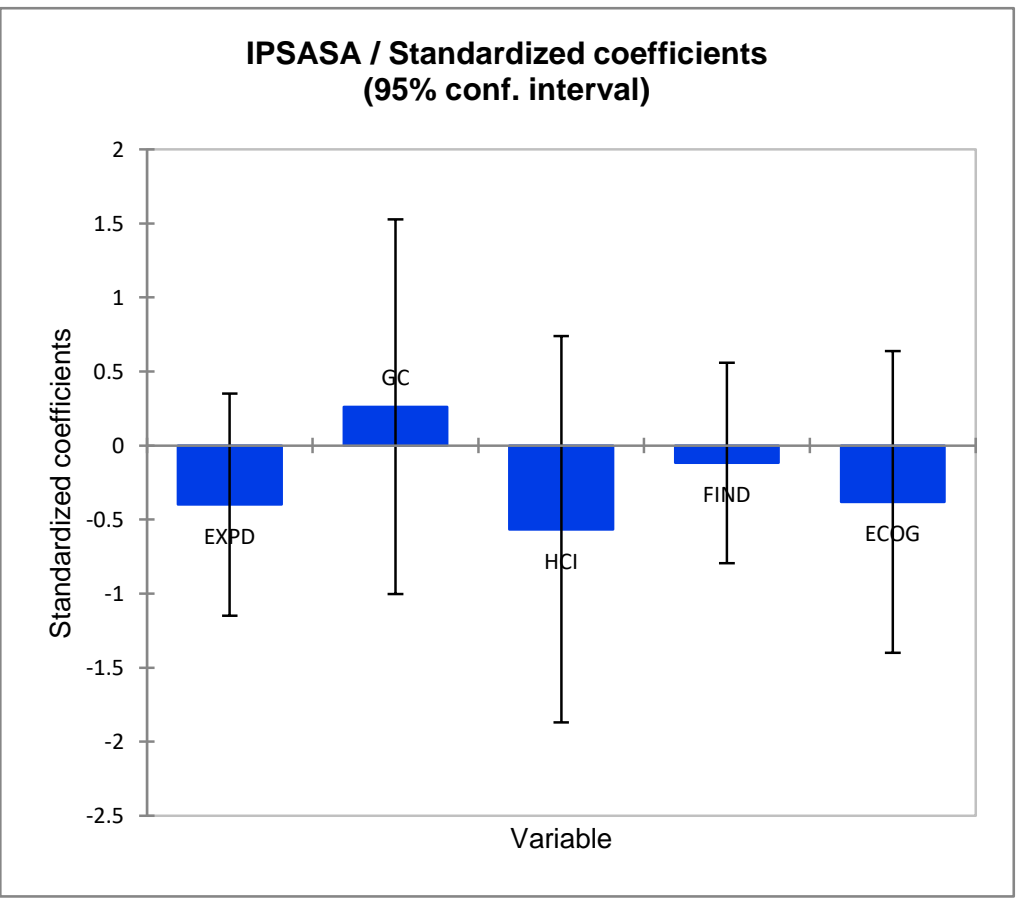


Predictions and residuals (Variable

IPSASA):

\begin{tabular}{|c|c|c|c|c|c|c|c|c|c|c|}
\hline $\begin{array}{l}\text { Obser } \\
\text { vation }\end{array}$ & $\begin{array}{c}\text { We } \\
\text { igh } \\
t\end{array}$ & $\begin{array}{c}\text { IPSA } \\
\text { SA }\end{array}$ & $\begin{array}{c}\text { Pred(I } \\
\text { PSAS } \\
\text { A) }\end{array}$ & $\begin{array}{l}\text { Ind } \\
\text { ep } \\
\text { en } \\
\text { de } \\
\text { nt }\end{array}$ & $\begin{array}{l}\text { IPSAS } \\
\text { A/We } \\
\text { ight }\end{array}$ & $\begin{array}{l}\text { Pred(I } \\
\text { PSAS } \\
\text { A)/W } \\
\text { eight }\end{array}$ & $\begin{array}{l}\text { St } \\
\text { d. } \\
\text { re } \\
\text { sid } \\
\text { ua } \\
\text { l }\end{array}$ & $\begin{array}{c}\text { Std. } \\
\text { residua } \\
\text { I } \\
\text { (Indep } \\
\text { endent } \\
\quad \\
\end{array}$ & $\begin{array}{c}\text { Lower } \\
\text { bound } \\
95 \%\end{array}$ & $\begin{array}{c}\text { Up } \\
\text { per } \\
\text { bou } \\
\text { nd } \\
95 \\
\% \\
\end{array}$ \\
\hline & & & & & & & 0. & & & \\
\hline & & & & 0.8 & & & 21 & & & 1.0 \\
\hline \multirow[t]{2}{*}{ Obs1 } & 1 & 1 & 0.955 & 62 & 1.000 & 0.955 & $\begin{array}{l}8 \\
0 .\end{array}$ & 0.400 & 0.087 & 00 \\
\hline & & & & 0.8 & & & 31 & & & 0.9 \\
\hline \multirow[t]{2}{*}{ Obs2 } & 1 & 1 & 0.912 & 62 & 1.000 & 0.912 & $\begin{array}{l}0 \\
0 .\end{array}$ & 0.400 & 0.638 & 84 \\
\hline & & & & 0.8 & & & 09 & & & 1.0 \\
\hline \multirow[t]{2}{*}{ Obs3 } & 1 & 1 & 0.991 & 62 & 1.000 & 0.991 & $\begin{array}{c}3 \\
0 .\end{array}$ & 0.400 & 0.309 & 00 \\
\hline & & & & 0.8 & & & 19 & & & 0.9 \\
\hline Obs4 & 1 & 1 & 0.962 & 62 & 1.000 & 0.962 & $\begin{array}{l}8 \\
0 .\end{array}$ & 0.400 & 0.674 & 97 \\
\hline \multirow[t]{2}{*}{ Obs5 } & 1 & 1 & 0.997 & $\begin{array}{r}0.8 \\
62\end{array}$ & 1.000 & 0.997 & $\begin{array}{r}05 \\
7 \\
- \\
2 .\end{array}$ & 0.400 & 0.229 & $\begin{array}{r}1.0 \\
00\end{array}$ \\
\hline & & & & 0.8 & & & 36 & & & 0.9 \\
\hline \multirow[t]{2}{*}{ Obs6 } & 1 & 0 & 0.849 & 62 & 0.000 & 0.849 & $\begin{array}{c}9 \\
0 .\end{array}$ & -2.500 & 0.327 & 85 \\
\hline & & & & 0.8 & & & 13 & & & 1.0 \\
\hline \multirow[t]{2}{*}{ Obs7 } & 1 & 1 & 0.982 & 62 & 1.000 & 0.982 & $\begin{array}{c}6 \\
- \\
1 .\end{array}$ & 0.400 & 0.522 & 00 \\
\hline & & & & 0.8 & & & 93 & & & 0.9 \\
\hline \multirow[t]{2}{*}{ Obs8 } & 1 & 0 & 0.790 & 62 & 0.000 & 0.790 & $\begin{array}{c}9 \\
0 .\end{array}$ & -2.500 & 0.195 & 83 \\
\hline & & & & 0.8 & & & 44 & & & 0.9 \\
\hline Obs9 & 1 & 1 & 0.833 & 62 & 1.000 & 0.833 & $\begin{array}{l}8 \\
0 .\end{array}$ & 0.400 & 0.276 & 85 \\
\hline \multirow[t]{2}{*}{ Obs10 } & 1 & 1 & 0.716 & $\begin{array}{r}0.8 \\
62\end{array}$ & 1.000 & 0.716 & $\begin{array}{r}63 \\
0 \\
0 .\end{array}$ & 0.400 & 0.058 & $\begin{array}{r}0.9 \\
90\end{array}$ \\
\hline & & & & 0.8 & & & 45 & & & 0.9 \\
\hline Obs11 & 1 & 1 & 0.831 & 62 & 1.000 & 0.831 & $\begin{array}{c}1 \\
0 .\end{array}$ & 0.400 & 0.352 & 78 \\
\hline \multirow[t]{2}{*}{ Obs12 } & 1 & 1 & 0.971 & $\begin{array}{r}0.8 \\
62\end{array}$ & 1.000 & 0.971 & $\begin{array}{r}17 \\
2 \\
0 .\end{array}$ & 0.400 & 0.392 & $\begin{array}{r}0.9 \\
99\end{array}$ \\
\hline & & & & 0.8 & & & 23 & & & 0.9 \\
\hline \multirow[t]{2}{*}{ Obs13 } & 1 & 1 & 0.949 & 62 & 1.000 & 0.949 & 2 & 0.400 & 0.600 & 96 \\
\hline & & & & 0.8 & & & 0. & & & 0.9 \\
\hline Obs14 & 1 & 1 & 0.927 & 62 & 1.000 & 0.927 & 28 & 0.400 & 0.322 & 97 \\
\hline
\end{tabular}




\begin{tabular}{|c|c|c|c|c|c|c|c|c|c|c|}
\hline & & & & & & & $\begin{array}{c}1 \\
0 .\end{array}$ & & & \\
\hline & & & & 0.8 & & & 13 & & & 1.0 \\
\hline Obs15 & 1 & 1 & 0.982 & 62 & 1.000 & 0.982 & 5 & 0.400 & 0.598 & 00 \\
\hline & & & & & & & 1. & & & \\
\hline & & & & 0.8 & & & 30 & & & 0.9 \\
\hline Obs16 & 1 & 0 & 0.629 & 62 & 0.000 & 0.629 & 1 & -2.500 & 0.105 & 61 \\
\hline & & & & & & & 1. & & & \\
\hline & & & & 0.8 & & & 22 & & & 0.9 \\
\hline Obs17 & 1 & 1 & 0.402 & 62 & 1.000 & 0.402 & 0 & 0.400 & 0.027 & 42 \\
\hline & & & & & & & 0. & & & \\
\hline & & & & 0.8 & & & 47 & & & 0.9 \\
\hline Obs18 & 1 & 1 & 0.819 & 62 & 1.000 & 0.819 & 0 & 0.400 & 0.310 & 79 \\
\hline & & & & & & & 1. & & & \\
\hline & & & & 0.8 & & & 02 & & & 0.9 \\
\hline Obs19 & 1 & 1 & 0.488 & 62 & 1.000 & 0.488 & 5 & 0.400 & 0.051 & 44 \\
\hline & & & & & & & 0. & & & \\
\hline & & & & 0.8 & & & 05 & & & 1.0 \\
\hline Obs20 & 1 & 1 & 0.997 & 62 & 1.000 & 0.997 & 5 & 0.400 & 0.547 & 00 \\
\hline & & & & & & & 0. & & & \\
\hline & & & & 0.8 & & & 21 & & & 0.9 \\
\hline Obs21 & 1 & 1 & 0.957 & 62 & 1.000 & 0.957 & 2 & 0.400 & 0.238 & 99 \\
\hline & & & & & & & 0. & & & \\
\hline & & & & 0.8 & & & 45 & & & 0.9 \\
\hline Obs22 & 1 & 1 & 0.829 & 62 & 1.000 & 0.829 & 4 & 0.400 & 0.296 & 82 \\
\hline & & & & & & & 0. & & & \\
\hline & & & & 0.8 & & & 34 & & & 0.9 \\
\hline Obs23 & 1 & 1 & 0.894 & 62 & 1.000 & 0.894 & 5 & 0.400 & 0.443 & 89 \\
\hline & & & & & & & 0. & & & \\
\hline & & & & 0.8 & & & 14 & & & 1.0 \\
\hline Obs24 & 1 & 1 & 0.980 & 62 & 1.000 & 0.980 & 1 & 0.400 & 0.131 & 00 \\
\hline & & & & & & & 0. & & & \\
\hline & & & & 0.8 & & & 34 & & & 0.9 \\
\hline Obs25 & 1 & 1 & 0.894 & 62 & 1.000 & 0.894 & 5 & 0.400 & 0.602 & 79 \\
\hline & & & & & & & 1. & & & \\
\hline & & & & 0.8 & & & 49 & & & 0.9 \\
\hline Obs26 & 1 & 0 & 0.690 & 62 & 0.000 & 0.690 & 2 & -2.500 & 0.208 & 50 \\
\hline & & & & & & & 0. & & & \\
\hline & & & & 0.8 & & & 25 & & & 0.9 \\
\hline Obs27 & 1 & 1 & 0.940 & 62 & 1.000 & 0.940 & 3 & 0.400 & 0.628 & 93 \\
\hline & & & & & & & 0. & & & \\
\hline & & & & 0.8 & & & 38 & & & 0.9 \\
\hline Obs28 & 1 & 1 & 0.871 & 62 & 1.000 & 0.871 & 6 & 0.400 & 0.343 & 89 \\
\hline & & & & & & & 0. & & & \\
\hline & & & & 0.8 & & & 19 & & & 0.9 \\
\hline Obs29 & 1 & 1 & 0.965 & 62 & 1.000 & 0.965 & 0 & 0.400 & 0.475 & 99 \\
\hline
\end{tabular}

Classification table for the training sample (Variable IPSASA):

\begin{tabular}{c|cc|c|c}
\hline $\begin{array}{c}\text { from } \backslash \\
\text { to }\end{array}$ & 0 & 1 & Total & $\begin{array}{c}\% \\
\text { cor }\end{array}$
\end{tabular}




\begin{tabular}{c|cc|c|c}
\hline & & & & $\begin{array}{c}\text { rec } \\
\mathrm{t}\end{array}$ \\
\hline & & & & 0.0 \\
0 & 0 & 4 & 4 & $0 \%$ \\
& & & & 92. \\
1 & 2 & 23 & 25 & $\%$ \\
\hline & & & & 79. \\
& & & & 31 \\
Total & 2 & 27 & 29 & $\%$ \\
\hline
\end{tabular}

ROC Curve (Variable IPSASA):

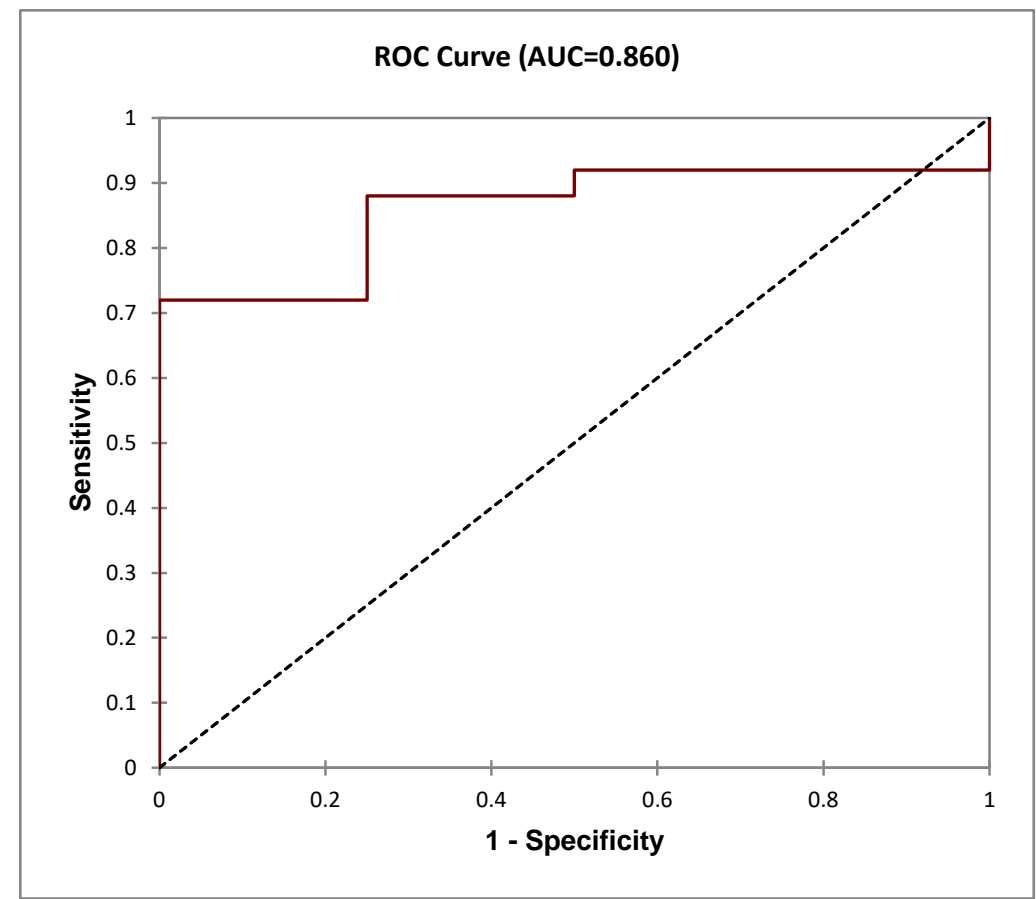

Area under

the curve: $\quad 0.86$ 